\title{
Parathyroid hormone secretion during exchange transfusion
}

\author{
R. D. G. MILNER and J. S. WOODHEAD \\ From the Department of Child Health, University of Manchester, and the Department of Medical Biochemistry, \\ Welsh National School of Medicine, Cardiff
}

\begin{abstract}
Milner, R. D. G. and Woodhead, J. S. (1975). Archives of Disease in Childhood, 50, 298. Parathyroid hormone secretion during exchange transfusion. Plasma concentrations of calcium, phosphate, citrate, albumin, and parathyroid hormone (PTH) were measured during and after exchange transfusion of infants suffering from haemolytic disease using blood anticoagulated with acid-citrate and dextrose (ACD) or heparin. Pretransfusion plasma PTH and phosphate both correlated positively with postnatal age but not with each other. Transfusion with ACD blood caused a twelvefold rise in plasma citrate levels but no significant change in plasma calcium, phosphate, or PTH of the infant, despite the concentration of these substances being lower in the donor blood. The concentration of calcium, phosphate, and albumin was higher in heparinized than in ACD donor blood, and infants transfused with heparinized blood showed no change in the plasma concentration of any substance measured during transfusion. The addition of $50 \mu \mathrm{g}$ glucagon to ACD donor blood had no effect on PTH secretion. 3 hours after transfusion there was a rise in the plasma PTH of infants who had received ACD blood but not in those given heparinized blood. Transfusion with ACD blood caused a net loss of calcium, phosphate, and albumin from the infant, whereas transfusion with heparin blood did not. Both types of transfusion caused a net loss of PTH but this was significantly greater in those given ACD blood.

These results show that transfusion with ACD blood results in increased secretion of PTH, probably due to the fall in ionized calcium concentration caused by the citrate load.
\end{abstract}

The effect of citrate in lowering the ionized serum calcium concentration of blood used for exchange transfusion has been calculated theoretically (Farquhar and Smith, 1958) and directly (Darnlow, 1971). More recently calcium specific electrodes have been used to show that the serum ionized calcium falls by half during exchange transfusion, that therapeutic calcium given during the procedure is ineffective, and that restoration of a normal serum ionized calcium concentration occurs spontaneously and rapidly after transfusion (Perkins et al., 1971; Radde et al., 1972; Gershanik, Levkoff, and Duncan, 1973; Maisels et al., 1974). In the adult cow a fall in serum ionized calcium stimulates parathyroid hormone (PTH) secretion (Sherwood et al., 1966) and for this reason we investigated the PTH response of the human infant during exchange

Received 4 September 1974. transfusion. Transfusions using blood preserved with acid-citrate and dextrose (ACD) were compared with transfusions in which heparinized blood was employed, and marked changes in serum ionized calcium were not expected to occur.

\section{Patients and methods}

Twenty-seven exchange transfusions were performed for hyperbilirubinaemia in infants suffering from haemolytic disease of the newborn. All transfusions were performed via the umbilical artery or vein as described previously (Milner et al., 1972; Cser and Milner, 1975). 10 transfusions were performed with ACD blood, 9 with ACD blood to which $50 \mu$ g glucagon had been added, and 8 with blood anticoagulated with heparin. The 10 infants having ACD transfusions were between 37 and 40 weeks' gestational age and 2.28 and $3.06 \mathrm{~kg}$ birthweight. The 7 infants having ACD + glucagon transfusions were 37 or 38 weeks' gesta- 
tional age and between $2 \cdot 25$ and $3.26 \mathrm{~kg}$ birthweight. The 7 infants having heparin transfusions were between 35 and 40 weeks' gestational age and $2 \cdot 12$ and $3.66 \mathrm{~kg}$ birthweight. 5 infants were studied more than once.

In blood samples collected before, during, and after transfusion as described previously (Milner et al., 1972; Cser and Milner, 1975), estimations were made of the haematocrit, plasma concentration of albumin (Doumas, Watson, and Biggs, 1971), calcium by atomic absorption spectrophotometry, phosphate (Fiske and Subbarow, 1925), and citrate (Zender, 1969). Plasma PTH concentration was measured by an immunoradiometric assay (Addison et al., 1971) using a guinea pig antibody raised to bovine PTH which showed good crossreactivity with human PTH. Before assay, samples were stored frozen at $-20^{\circ} \mathrm{C}$. Samples were assayed against a reference preparation of human PTH (kindly provided by Dr. J. L. H. O'Riordan) which was $2.5 \%$ pure using an antiserum (code 71/69) generously provided by the Medical Research Council. The lower limit of detection of the assay was $0.1 \mathrm{ng} / \mathrm{ml}$ and for the purposes of statistical calculation plasma samples in which PTH could not be detected were assigned a value of $0.1 \mathrm{ng} / \mathrm{ml}$.

\section{Results}

Before transfusion. The infants in the 3 groups were comparable in gestational age, birthweight, and pathology. Ages at the start of transfusion ranged from 4 to 137 hours. Plasma PTH concentration before transfusion was positively correlated with postnatal age (Fig.) $(r=0.408$; $P<0.05)$. Cases 1 and 2 who had high plasma PTH concentrations in the first day of life were rhesus-affected female twins of 37 weeks' gestation and birthweights $2 \cdot 28$ and $2 \cdot 66 \mathrm{~kg}$. Pretransfusion plasma phosphate also increased with postnatal age $(r=0.448 ; P<0.05)$, but there was no correlation between pretransfusion plasma PTH and phosphate concentrations, and no significant relation between pretransfusion plasma calcium or albumin and postnatal age.

With the exception of phosphate, donor blood concentrations of all substances were similar in the two types of ACD transfusion and these were pooled for comparison of ACD with heparin donor blood (Table I). Mean plasma concentration of albumin and calcium in ACD donor blood was lower than that in heparin donor blood due to the diluting effect of $120 \mathrm{ml}$ ACD solution in each unit of blood. Plasma phosphate in the ACD donor blood was low for the same reason, and in heparin donor blood the phosphate concentration was raised due to the presence of phosphate buffer in the plastic collecting bags. ${ }^{\star}$ PTH was undetectable in 11 of

^Fenwal Blood Pack, Travenol Laboratories Ltd.

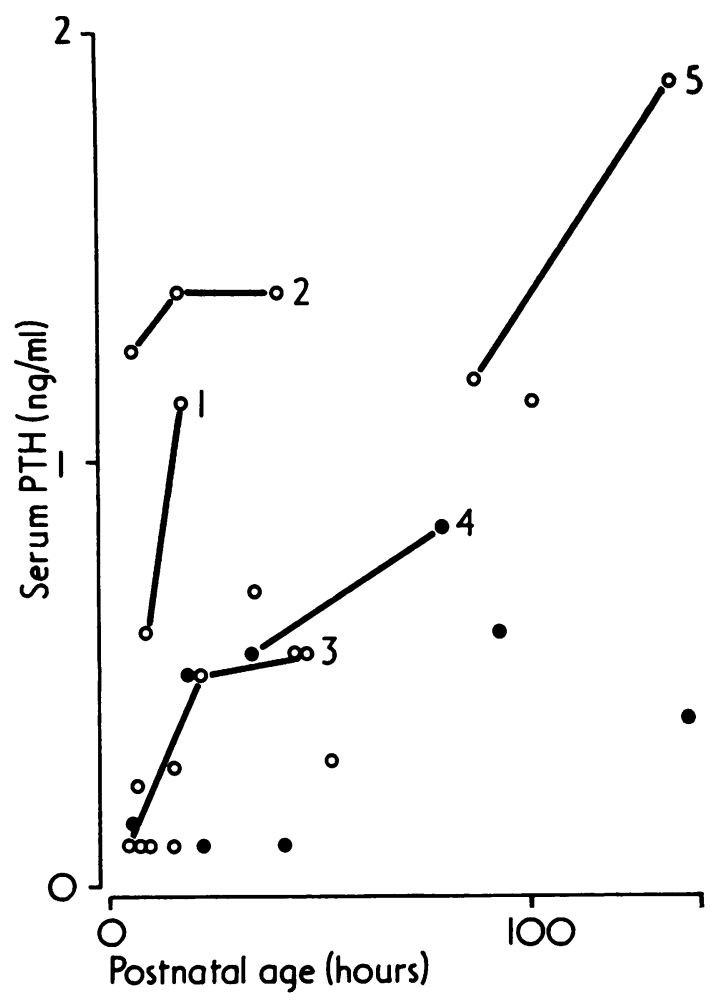

Fig.-Scatterdiagram of pretransfusion serum PTH plotted against postnatal age. Lines join observations made on the same infant. Infants 1 and 2 were twins. $A C D$ transfusions @; heparin transfusions $\bigcirc$.

the 19 ACD donor blood samples and in 3 of the 8 heparin donor samples.

At the start of transfusion mean plasma concentration of phosphate was higher and calcium significantly lower in infants transfused with heparinized blood than in those receiving ACD blood (Table I). This was probably a small sample phenomenon in that in each case the heparin group differed significantly from only one of the two ACD subgroups which were of similar size.

During transfusion. During transfusion the plasma concentration of all substances in the infants receiving $A C D$ blood did not differ significantly from that of those transfused with ACD blood enriched with glucagon. It was concluded that glucagon was without effect on plasma albumin, calcium, citrate, phosphate, or PTH during exchange transfusion and the results of the two groups were pooled for comparison with the changes taking place during heparin transfusion. 
Mean $( \pm S E)$ plasma concentration of albumin, phosph hate,

\begin{tabular}{|c|c|c|}
\hline Substance measured & Donor & $0 \mathrm{ml} \stackrel{\overrightarrow{\bar{G}}}{\vec{H}}$ \\
\hline $\begin{array}{l}A C D \text { transfusions } \\
\text { Albumin }(\mathrm{g} / 100 \mathrm{ml}) \\
\text { Phosphate }(\mathrm{mg} / 100 \mathrm{ml}) \\
\text { Calcium }(\mathrm{mg} / 100 \mathrm{ml}) \\
\text { Citrate }(\mathrm{g} / 1) \\
\text { PTH }(\mathrm{ng} / \mathrm{ml})\end{array}$ & $\begin{array}{l}2 \cdot 80 \pm 0 \cdot 13(9) \\
2 \cdot 98 \pm 0 \cdot 29(9) \\
5 \cdot 54 \pm 0 \cdot 31(9) \\
4 \cdot 57 \pm 0 \cdot 18(9) \\
0 \cdot 22 \pm 0.06(10)\end{array}$ & 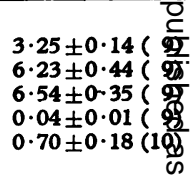 \\
\hline $\begin{array}{l}\text { ACD + glucason transfusions } \\
\text { Albumin }(\mathrm{g} / 100 \mathrm{ml}) \\
\text { Phosphate }(\mathrm{mg} / 100 \mathrm{ml}) \\
\text { Calcium }(\mathrm{mg} / 100 \mathrm{ml}) \\
\text { Citrate }(\mathrm{g} / \mathrm{l}) \\
\text { PTH }(\mathrm{ng} / \mathrm{ml})\end{array}$ & $\begin{array}{l}2 \cdot 79 \pm 0 \cdot 10(9) \\
2 \cdot 22 \pm 0 \cdot 19(9) \star \\
5 \cdot 28 \pm 0 \cdot 15(9) \\
4 \cdot 29 \pm 0 \cdot 12(9) \\
0 \cdot 11 \pm 0 \cdot 06(9)\end{array}$ & 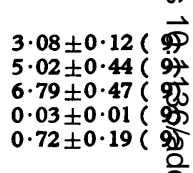 \\
\hline $\begin{array}{l}\text { All ACD transfusions } \\
\text { Albumin }(\mathrm{g} / 100 \mathrm{ml}) \\
\text { Phosphate }(\mathrm{mg} / 100 \mathrm{ml}) \\
\text { Calcium }(\mathrm{mg} / 100 \mathrm{ml}) \\
\text { Citrate }(\mathrm{g} / \mathrm{l}) \\
\text { PTH }(\mathrm{ng} / \mathrm{ml})\end{array}$ & $\begin{array}{l}2 \cdot 80 \pm 0.08(18) \\
2 \cdot 85 \pm 0 \cdot 17(18) \\
4 \cdot 40 \pm 0 \cdot 16(18) \\
4 \cdot 43 \pm 0 \cdot 11(18) \\
0 \cdot 17 \pm 0.04(19)\end{array}$ & $\begin{array}{r}3.16 \pm 0.09 \text { (18 } \\
5.62 \pm 0.31 \text { (18) } \\
6.67 \pm 0.29(18) \\
0.04 \pm 0.01 \text { (18) } \\
0.71 \pm 0.13 \text { (1990 } \\
\text { 으 }\end{array}$ \\
\hline $\begin{array}{l}\text { Heparin transfusions } \\
\text { Albumin }(\mathrm{g} / 100 \mathrm{ml}) \\
\text { Phosphate }(\mathrm{mg} / 100 \mathrm{ml}) \\
\text { Calcium }(\mathrm{mg} / 100 \mathrm{ml}) \\
\text { PTH }(\mathrm{ng} / \mathrm{ml})\end{array}$ & $\begin{array}{l}3.98 \pm 0.17(8) \ddagger \\
9 \cdot 16 \pm 0.63(8) \ddagger \\
6.66 \pm 0.11(8) \ddagger \\
0.24 \pm 0.04(8)\end{array}$ & $\begin{array}{l}3.25 \pm 0.18(8) \\
7.05 \pm 0.39(8) \\
5.80 \pm 0.27(8) \\
0.41 \pm 0.10(8)\end{array}$ \\
\hline
\end{tabular}

Level of significance $: \star P<0.05,+P<0.01, \neq P<0.001$ for comparison of heparin transfusion with all ACD transfusions, or of ACD + glucagon transfusions with ACD transfusions. No. of observations shown in parentheses.

During ACD transfusion there was a gradual fall in plasma albumin concentration so that at the end of transfusion the mean concentration was similar to that in the donor blood. In heparin transfusions the mean plasma albumin rose to a level halfway between that in the infant before transfusion and that in the donor blood. Mean plasma albumin concentrations were significantly higher in heparin transfusions from the $200 \mathrm{ml}$ point onwards.

A similar change took place in plasma phosphate concentration during heparin transfusions, but during ACD transfusion there was no fall in plasma phosphate despite the donor plasma phosphate being half that in the infant before transfusion. Likewise, plasma calcium level in ACD transfusions remained steady despite the mean donor plasma calcium being two-thirds that of the infants' before transfusion.

In both types of transfusion the pretransfusion mean plasma PTH was higher than that in the donor blood and was maintained at a relatively constant level throughout. The wide variation in plasma levels between infants, partly a function of postnatal age, meant that though the plasma PTH levels in ACD transfusions were almost twice as high as in heparin transfusions there was no significant difference between the two groups. In 4 infants aged 4, 4, 6, and 15 hours receiving ACD transfusions, no PTH was detectable at any time. Despite the citrate concentration in the donor blood being 100 times higher than that in the infant, the mean plasma citrate level in the infant rose only twelvefold during the procedure.

Analysis of the total amounts of each substance injected and withdrawn from the infants revealed marked differences between ACD and heparin transfusions (Table II). ACD transfusions were characterized by a significant net loss of calcium, phosphate, and albumin, whereas in heparin transfusions no significant loss or accumulation of these substances by the infant occurred. In both types of transfusion there was a net loss of PTH but this was three times greater in ACD than in heparin transfusions. If the ACD transfusions in which PTH was never detected were included in the calculation of net PTH loss, the figure became $54 \cdot 71 \pm 12 \cdot 01 \mathrm{ng} / \mathrm{kg}$, which was not significantly greater than that occurring in heparin transfusions. The net balances of PTH in the 5 infants who had more than one transfusion are shown in Table III. In 3 PTH loss increased and in the other 2 PTH loss was high in all transfusions.

After transfusion. Blood samples were col- 
calcium, citrate, and PTH during exchange transfusion

\begin{tabular}{|c|c|c|c|}
\hline $100 \mathrm{ml}$ & $200 \mathrm{ml}$ & $300 \mathrm{ml}$ & $400 \mathrm{ml}$ \\
\hline $\begin{array}{l}3.06 \pm 0.13(9) \\
6.27 \pm 0.47(9) \\
6.69 \pm 0.33(9) \\
0.38 \pm 0.03(9) \\
0.69 \pm 0.17(10)\end{array}$ & $\begin{array}{l}3.02 \pm 0.11(9) \\
6.30 \pm 0.46(9) \\
6.72 \pm 0.38(9) \\
0.46 \pm 0.05(9) \\
0.73 \pm 0.16(10)\end{array}$ & $\begin{array}{l}2.91 \pm 0.09(9) \\
6.39 \pm 0.42(9) \\
6.85 \pm 0.32(9) \\
0.56 \pm 0.07(9) \\
0.71 \pm 0.16(10)\end{array}$ & $\begin{array}{l}2 \cdot 83 \pm 0.10(9) \\
6 \cdot 39 \pm 0.39(9) \\
7 \cdot 11 \pm 0.41(9) \\
0.54 \pm 0.06(9) \\
0.65 \pm 0.14(10)\end{array}$ \\
\hline $\begin{array}{l}2.90 \pm 0.07(9) \\
5.41 \pm 0.39(9) \\
6.75 \pm 0.42(9) \\
0.35 \pm 0.03(9) \\
0.69 \pm 0.19(9)\end{array}$ & $\begin{array}{l}2.80 \pm 0.09(9) \\
5.50 \pm 0.39(9) \\
6.73 \pm 0.39(9) \\
0.43 \pm 0.03(9) \\
0.71 \pm 0.21(9)\end{array}$ & $\begin{array}{l}2.72 \pm 0.08(9) \\
5.52 \pm 0.35(9) \\
6.86 \pm 0.38(9) \\
0.52 \pm 0.13(9) \\
0.88 \pm 0.26(9)\end{array}$ & $\begin{array}{l}2 \cdot 63 \pm 0.09(9) \\
5 \cdot 35 \pm 0.32(9) \\
6 \cdot 77 \pm 0.29(9) \\
0.53 \pm 0.19(9) \\
0.77 \pm 0.20(9)\end{array}$ \\
\hline $\begin{array}{l}2 \cdot 98 \pm 0.07(18) \\
5 \cdot 84 \pm 0.30(18) \\
6 \cdot 72 \pm 0.27(18) \\
0.37 \pm 0.02(18) \\
0.69 \pm 0.12(19)\end{array}$ & $\begin{array}{l}2.91 \pm 0.07(18) \\
5.90 \pm 0.30(18) \\
6.72 \pm 0.27(18) \\
0.45 \pm 0.03(18) \\
0.72 \pm 0.12(19)\end{array}$ & $\begin{array}{l}2.82 \pm 0.06(18) \\
5.95 \pm 0.27(18) \\
6.86 \pm 0.25(18) \\
0.54 \pm 0.04(18) \\
0.79 \pm 0.14(19)\end{array}$ & $\begin{array}{l}2 \cdot 73 \pm 0.07(18) \\
5 \cdot 87 \pm 0.25(18) \\
6.94 \pm 0.25(18) \\
0.53 \pm 0.04(18) \\
0.71 \pm 0.11(19)\end{array}$ \\
\hline $\begin{array}{l}3 \cdot 28 \pm 0 \cdot 18(8) \\
7 \cdot 52 \pm 0 \cdot 48(8) t \\
6 \cdot 46 \pm 0 \cdot 26(8) \\
0 \cdot 45 \pm 0 \cdot 11(8)\end{array}$ & $\begin{array}{l}3 \cdot 34 \pm 0 \cdot 13(8) \dagger \\
7 \cdot 72 \pm 0.51(8) \dagger \\
6 \cdot 44 \pm 0.30(8) \\
0 \cdot 44 \pm 0 \cdot 11(8)\end{array}$ & $\begin{array}{l}3 \cdot 46 \pm 0.16(8) \ddagger \\
7 \cdot 78 \pm 0.39(8) \ddagger \\
6 \cdot 45 \pm 0.37(8) \\
0.43 \pm 0.10(8)^{\star}\end{array}$ & $\begin{array}{l}3 \cdot 58 \pm 0 \cdot 13(6) \ddagger \\
8 \cdot 47 \pm 0.57(6) \ddagger \\
6 \cdot 92 \pm 0.22(6) \\
0.37 \pm 0.12(6)^{\star}\end{array}$ \\
\hline
\end{tabular}

lected hourly for 3 hours after ACD transfusion in 8 infants and at 3 hours after transfusion in 6 who had received heparinized blood. In 1 of the $8 \mathrm{PTH}$ was never detected. The mean $( \pm S E)$ plasma PTH concentration at the end of transfusion in 7 infants was $0.29 \pm 0.09 \mathrm{ng} / \mathrm{ml}$, in 7 infants at 1 hour $0 \cdot 26 \pm 0.08 \mathrm{ng} / \mathrm{ml}$, in 6 at 2 hours $0 \cdot 37 \pm 0 \cdot 14$ $\mathrm{ng} / \mathrm{ml}$, and in 5 at 3 hours $0 \cdot 44 \pm 0 \cdot 16 \mathrm{ng} / \mathrm{ml}$. Paired analysis showed that a small but significant rise in plasma PTH of $0.13 \pm 0.04 \mathrm{ng} / \mathrm{ml}$ occurred 3 hours after transfusion. The mean $( \pm S E)$ plasma PTH of the 6 infants receiving heparinized blood was $0.38 \pm 0.12 \mathrm{ng} / \mathrm{ml}$ at the end of transfusion and $0 \cdot 37 \pm 0 \cdot 11 \mathrm{ng} / \mathrm{ml} 3$ hours later.

TABLE II

Amounts of albumin, calcium, phosphate, citrate, and PTH infused and removed during exchange transfusion with $A C D$ or heparin blood

\begin{tabular}{|c|c|c|c|}
\hline \multirow{2}{*}{ Metabolite or hormone } & \multicolumn{3}{|c|}{ Mean $\pm S E M$ amount infused or removed/kg body weight } \\
\hline & In & Out & Balance \\
\hline $\begin{array}{l}\text { ACD transfusions } \\
\text { Calcium (mg) } \\
\text { Phosphate (mg) } \\
\text { Citrate (mg) } \\
\text { Albumin (g) } \\
\text { PTH (ng) }\end{array}$ & $\begin{array}{c}3 \cdot 67 \pm 0 \cdot 16 \\
1 \cdot 78 \pm 0 \cdot 12 \\
311 \pm 13 \\
1 \cdot 92 \pm 0 \cdot 12 \\
13 \cdot 52 \pm 3 \cdot 56\end{array}$ & $\begin{array}{r}5 \cdot 73 \pm 0.35(18) \\
4 \cdot 89 \pm 0 \cdot 30(18) \\
36 \cdot 1 \pm 2 \cdot 5(18) \\
2 \cdot 44 \pm 0 \cdot 11(18) \\
83 \cdot 10 \pm 13 \cdot 60(15)\end{array}$ & $\begin{array}{l}-2 \cdot 06 \pm 0.29 t \\
-3.11 \pm 0.24 t \\
+275 \pm 12 \\
-0.52 \pm 0.04 t \\
-69.58 \pm 12.60^{\star}\end{array}$ \\
\hline $\begin{array}{l}\text { Heparin transfusions } \\
\text { Calcium (mg) } \\
\text { Phosphate (mg) } \\
\text { Albumin (g) } \\
\text { PTH (ng) }\end{array}$ & $\begin{array}{r}6 \cdot 14 \pm 0 \cdot 45 \\
8 \cdot 47 \pm 0 \cdot 84 \\
3 \cdot 68 \pm 0 \cdot 32 \\
21 \cdot 13 \pm 3 \cdot 23\end{array}$ & $\begin{array}{r}6 \cdot 43 \pm 0.39(8) \\
7 \cdot 77 \pm 0.67(8) \\
3 \cdot 41 \pm 0.25(8) \\
44 \cdot 37 \pm 10 \cdot 72(8)\end{array}$ & $\begin{array}{l}-0.28 \pm 0.30 \\
+0.70 \pm 0.41 \\
+0.27 \pm 0.14 \\
-23 \cdot 24 \pm 12.49\end{array}$ \\
\hline
\end{tabular}

Level of significance. ${ }^{\star} P<0.05 .+P<0.001$ for comparison with heparin transfusions.

No. of observations shown in parentheses. 
TABLE III

Net balance of PTH $(\mathrm{ng} / \mathrm{kg})$ in infants who had more than one exchange transfusion

\begin{tabular}{|c|c|c|c|}
\hline \multirow{2}{*}{ Case no. } & \multicolumn{3}{|c|}{ Exchange transfusion } \\
\hline & 1 & 2 & 3 \\
\hline $\begin{array}{l}1 \\
2 \\
3 \\
4 \\
5\end{array}$ & $\begin{array}{c}-51 \cdot 2(8) \\
-118 \cdot 1(5) \\
-\quad 2 \cdot 8(4) \\
-109 \cdot 7(86)\end{array}$ & $\begin{array}{c}-92 \cdot 2(17) \\
-111 \cdot 6(16) \\
-34 \cdot 0(21) \\
-52 \cdot 5(33) \\
-\end{array}$ & $\begin{array}{l}- \\
-129 \cdot 6(39) \\
-33 \cdot 0(46) \\
-94 \cdot 2(78) \\
-128 \cdot 5(132)\end{array}$ \\
\hline
\end{tabular}

Figures in parentheses show age in hours at which transfusion occurred.

\section{Discussion}

This study has shown that infants respond to exchange transfusion with ACD blood by increasing PTH secretion, the evidence being the greater net loss of PTH during transfusions with ACD blood than with heparinized blood and the rise in plasma PTH 3 hours post-transfusion. One difficulty in comparing two groups of exchange transfusions stems from the rise of plasma PTH levels with postnatal age. The most striking feature of individual transfusions was that the plasma PTH level remained relatively constant despite the donor plasma PTH being usually lower. These findings are partly in agreement with those of Tsang et al. (1973) who observed no rise in plasma PTH in paired samples during the first week of life and who claim to have shown an increase of PTH secretion during ACD exchange transfusion which was dependent on both gestational and postnatal age. The range of gestational age of our infants was too narrow for comment on the first point but the positive correlation of pretransfusion PTH with postnatal age suggests that the resting level of secretion increases after birth as did the secretory response to ACD in 3 of the 5 infants who had more than one transfusion.

The heparin transfusions were studied as a control group for comparison with ACD transfusions. Unfortunately, in addition to the difference in citrate, and hence ionized calcium concentration, the diluting effect of $120 \mathrm{ml}$ ACD solution and the presence of phosphate buffer in the heparin collection bags resulted in significant differences in the total plasma calcium, phosphate, and albumin concentrations between the two types of donor blood. Plasma albumin concentration in both types of transfusion and plasma calcium and phosphate concentrations in the heparin transfusions rose or fell towards the donor level as the transfusion progressed. In contrast, plasma cal- cium and phosphate concentrations during ACD transfusions did not fall despite appreciably lower donor levels. The mobilization of calcium and phosphate from the extravascular compartment maintained homoeostasis of plasma concentrations as shown by the significant negative net balance of each substance occurring in ACD but not in heparin transfusions. This was probably due to increased PTH secretion, though it was not proven.

The addition of $50 \mu \mathrm{g}$ glucagon to ACD blood results in high plasma glucagon in the infant by the end of transfusion with effects on glucose mobilization and insulin secretion (Milner, Chouksey, and Assan, 1973). Glucagon has been reported to stimulate calcitonin release from perfused thyroid glands (Care, Bates, and Gitelman, 1970) and indirect evidence suggests that chronic hyperglucagonaemia may lead to parathyroid hyperplasia (Paloyan, 1967). It was of interest then to see if raising plasma glucagon levels had any acute effect on calcium balance or PTH release during exchange transfusion. The negative results may have been caused by glucagon having no effect on the PTH secreting cell or because the citrate load was already causing maximum stimulation of PTH secretion.

The finding of an increased PTH secretion after birth fits well with the morphological observations of Kaplan (1942), who noted that parathyroid hypertrophy occurred in 11 of 13 infants dying between the fourth and tenth day of life but in none of 20 dying during the first 3 days.

We are grateful to Professors J. A. Davis and C. N. Hales for their encouragement; to Drs. S. K. Chouksey and A. Cser who collected the blood samples; and to Mrs.P. Better and Mrs. N. Toner for technical assistance.

\section{REIERRENCES}

Addison, G. M., Hales, C. N., Woodhead, J. S., and O'Riordan J. L. H. (1971). Immunoradiometric assay of parathyroid hormone. Fournal of Endocrinology, 49, 521.

Care, A. D., Bates, R. F., and Gitelman, H. J. (1970). A possible role for the adenyl cyclase system in calcitonin release. Fournal of Endocrinology, 48, 1.

Cser, A., and Milner, R. D. G. (1975). Metabolic and hormonal consequences of exchange transfusion via the umbilical artery or vein. Biology of the Neonate. (In the press.)

Darnlow, U. (1971). Untersuchungen des ionisierten Serumkalziums bei der Austauschtransfusion im Neugenborenenalter. Deutsche Gesundheitsivesen, 26, 1949.

Doumas, B. T., Watson, W. A., and Biggs, H. G. (1971). Albumin standards and the measurement of serum albumin with bromcresol green. Clinica Chimica Acta, 31, 87.

Farquhar, J. W., and Smith, H. (1958). Clinical and biochemical changes during exchange transfusion. Archives of Disease in Childhood, 33, 142.

Fiske, C. H., and Subbarow, Y. (1925). Colorimetric determination of phosphorus. Fournal of Biological Chemistry, 66, 375.

Gershanik, J. J., Levkoff, A. H., and Duncan, R. (1973). Serum ionized calcium values in relation to exchange transfusion. Fournal of Pediatrics, 82, 847. 
Kaplan, E. (1942). The parathyroid gland in infancy. Archives of Pathology, 34, 1042.

Maisels, M. J., Li T-K, Piechocki, J. T., and Werthman, M. W. (1974). The effect of exchange transfusion on serum ionized calcium. Pediatrics, 53, 683.

Milner, R. D. G., Chouksey, S. K., and Assan, R. (1973). Metabolic and hormonal effects of glucagon infusion in erythroblastotic infants. Archives of Disease in Childhood, 48, 885.

Milner, R. D. G., Fekete, M., Assan, R., and Hodge, J. S. (1972). The effect of glucose on plasma glucagon, growth hormone, and insulin in exchange transfusion. Archives of Disease in Childhood, 47, 179.

Paloyan, E. (1967). Recent developments in the early diagnosis of hyperparathyroidism. Surgical Clinics of North America. 47, 61 .

Perkins, H. A., Snyder, M., Thacher, C., and Rolfs, M. R. (1971) Calcium ion activity during rapid exchange transfusion with citrated blood. Transfusion, 11, 204.
Radde, I. C., Parkinson, D. K.: Höffken, B., Appiah, K. E., and Hanley, W. B. (1972). Calcium ion activity in the sick neonate: effect of bicarbonate administration and exchange transfusion. Pediatric Research, 6, 43.

Sherwood, L. M. Potts, J. T., Care, A. D., Mayer, G. P., and Auerbach, G. D. (1966). Evaluation by radioimmunoassay of factors controlling the secretion of parathyroid hormone. Nature, 209, 52.

Tsang, R. C., Chen, I-W., Friedman, M. A., and Chen, I. (1973) Neonatal parathyroid function: role of gestational age and postnatal age. Fournal of Pediatrics, 83, 728.

Zender, R. (1969). Analyse du citrate plasmatique par voie enzymatique sans deproteinisation. Clinicu Chimica Acta, 24, 335.

Correspondence to Dr. R. D. G. Milner, Room 61, Research Floor, St. Mary's Hospital, Manchester 13 0JH. 